\title{
A TRIP TO KABUL
}

(October 15 to 21,1993 )

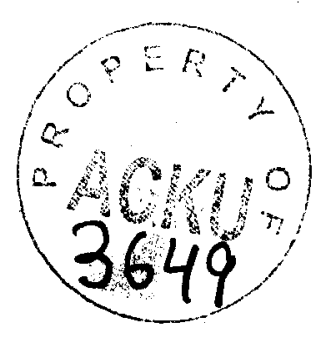

Charles MacFadden, ACBAR Executive Director Mohd Ismail Shakir, ACBAR Program Manager

\section{OBJECTIVES :}

1. To sign a protocol agreement with the Government of Islamic state of Afghanistan.

2. To discuss the rules and regulations for NGOs, as determined by the Ministry of Planning.

3. To look at the possibilities of finding a suitable building for an ACBAR office.

4. To attend the ACBAR Logar Coordination Meeting in Puli Alam.

5. To meet with Kabul-based agencies.

\section{GEIERAL SITUATION:}

Kabul was found to be more peaceful and alive this time, as compared to the last trip made in late July. There have been considerable improvements in the city over the past three months - especially related to security. However, there was no electricity because of fighting in sarobi and little access to running water. Prices of all daily used commodities (eg. fuel, flour, rice, cooking oil, etc.) have gone up by some 30-40 percent, as a result of the closure of the road between Jalalabad and Kabul. With winter coming there will be major problems for the people of the city if the road is blocked for any length of time - the road was temporarily opened as we left the city but may apparently be closed again in a few days. There could be considerable hardship over the coming months if the current problems persist. 
The overall security was good. In most Government buildings there are now uniformed soldiers/security guards and in some of these e.g. the Ministry of Foreign Affairs, visitors are no longer searched.

It is, however, mentioned with deep regret that two chowkidars of Afghanaid were killed on the night of Thursday October 14 at their office in Shahr-e-Naw by a group of unknown armed people. The relevant Government departments were contacted by Afghanaid staff and they have promised assistance. The office has already been provided with armed guards.

The issue was also brought up in a meeting between ACBAR Director and the Deputy Mirister of Foreign Affairs, who proposed that NGOs should either have offices in one area like Wazir Akbar Khan where the Government will take the security of the whole area; or they can be dealt with like diplomatic missions whose offices will be provided armed guards.

\section{PROTOCOL:}

ACBAR signed a protocol agreement with the GISA on Wednesday October 20, 1993.

It is a special protocol in that both the Ministry of Foreign Affairs and the Ministry of Planning have signed it. The Government, considering the special status of ACBAR as a coordinating body, agreed on several special points in the protocol.

So far, a total of 24 NGOs have signed protocol with the GISA (list of agencies that have signed a protocol is attached). The Deputy Minister of Foreign Affairs was of the view that NGos working anywhere in Afghanistan should sign the protocol as soon as possible. Otherwise, their activities will be appraised invalid by the Government in the future. It is felt that the protocol agreement between NGOs and the Government will be a moral support to the central Government and will promote the sovereignty of the Islamic state of Afghanistan.

Copy of the protocol agreement signed between ACBAR and the GISA is attached.

\section{REGULATIONS FOR NGO WORK:}

The Ministry of Planning has produced two sets of rules and regulations; one for Afghan and another for International NGos. The issue was discussed in the meetings with the authorities of the Ministry. ACBAR proposed a number of changes some of which were accepted. There are a few other points still to be reviewed as they may not be applicable with NGOs. 
The drafts of the regulations have been submitted to the higher echelons of the government for approval and endorsement. Copies of the draft of the regulations are available at ACBAR and are being translated. Further discussions will take place next visit.

No agency has been registered with the Ministry of Planning so far. An office has been established in the Ministry of Planning to deal with NGOs.

\section{ACBAR SUB-OFFICE IN KABUL:}

ACBAR may soon open a sub-office/guest house in Kabul. Several houses were looked at. Another trip will be made to finalize the issue.

There are houses available to be rented for offices but rather expensive. NGOs are seen as wealthy foreign enterprises because of which they are expected to pay higher than the market prices.

\section{LOGAR MEETING :}

According the decision of the last meeting of ACBAR Logar Coordination Group the October meeting was held in Puli Alam, the capital of Logar.

Some of the provincial authorities as well. as shura members/ district officers of some of the districts were invited to the meeting. NGOs reported on their ongoing activities and planned programs. The provincial authorities highlighted the needs of the area and requested NGOs to consider them (a list of priorities indicated by Logar authorities is attached).

The meeting proved very useful and informative as most of the participants representing NGOs were field staff. They shared much. valuable information, some of which is not available to Peshawar staff and, hence, cannot be shared in Peshawar meetings.

The main problem of NGOs was the differences between labor wages. There was also some overlapping of projects (at survey stage) mainly in digging drinking water wells.

The authorities of the province requested that NGOs should keep them updated on the rehabilitation programs.

CARE International hosted the meeting at their provincial office.

It is suggested that in future many more such meetings are held in Logar; and this is recommended for other provinces as well. 


\section{AGENCIES BASED IN KABUL:}

A number of agencies either based/or with offices in Kabul were visited (ICRC, UNDP, IAM, Habitat, GAA/AHED, Halo Trust, BDS, AVICEN, SCA and Afghanaid). Some of the agencies were given forms to provide information for the directory.

A number of Habitat supported projects in the old City/Chindawul area were also visited. These are small projects and include flood control, assistance for flood damaged houses, building walkways for the houses on the mountains lopes, removal of household rubbish and wells for drinking water. These are mostly self-help type activities and are based on community cooperation and use of their own resources. The projects were found very appropriate and cost effective. It is recommended that staff of NGOS involved in such activities should visit them as model for community participation and contribution.

Copies of ACBAR database were distributed to:
- Ministry of Foreign Affairs - 5 copies
- $\quad$ Ministry of Planning - 4 copies
- $\quad$ Ministry of Education - 3 copies
- Ministry of Public Health - 3 copies
- $\quad$ NGos and other agencies - 10

$\star * * * * * * * * * * * * *$

We want to extend our thanks to SCA for providing accommodation and to all other organizations and government departments for their cooperation.

October 25, 1993

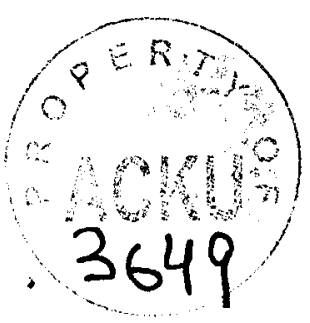


WORK PRIORITIES FOR NGOS WORKING IN LOGAR

(as identified by Logar authorities)

1. Secondary roads mainly linking Puli Alam to the districts and sub-districts should be repaired. Also there are a number "of bridges along these roads to be repaired. List available with the government office.

2. Improved seed and fertilizer should be provided as rust has attacked most parts of the province. Also agro-chemicals for plant protection should be provided.

3. Veterinary services should be expanded and the number of veterinary units be increased.

4. " schools, mosques and clinics be built in each district.

5. Administrative buildings be repaired/built in the provincial capital as well as the district centers.

6. There are two dams in Logar (Surkhab and Kherwar) which need some rehabilitation work and there is potential for a new dam to be constructed in Deh Naw. Kherwar dam was originally constructed for a hydro-electric power station. NGOs who have the capacity should consider completing this.

7. Deep wells to be constructed in the villages for drinking water and in the dessert for irrigation.

8. Communication lines between the province center and the districts be set up. 
1. German Agro Action

2. AHED

3. Sandy Gall Afghanistan Appeal

4. Swedish Committee for Afghanistan

5. German Afghanistan Foundation

6. Norwegian Refugee Council/Norwegian Church Aid

7. Solidarites Afghanistan

8. Afghanaid

9. Afghanistan Reconstruction and Planning Department

10. Global Partners UK

11 SERVE

12. Orphans Refugees and Aid

13. Shelter Now International

14. Radda Barnen

15. Medical Refresher Courses for Afghans

16. Islamic Relief Agency

17. Bomb Disposal Service

18. Medicines du Mond

19. Solidarites Afghanistan Belgium

20. MADERA

21. Norwegian Afghanistan Committee

22. Afghan Technical Assistance

23. CARE International

24. ACBAR 


\section{Ministry of Planning}

1. Mr. Ali Jawed, Minister

2. Dr. Sultan Hussain, Deputy Minister

3. Dr. Farahmand, Head of Planning Department

4. Eng. Zia, Head of External Relations Department

5. Mr. Zamani, Head of NGO Office

\section{Ministry of Foreign Affairs}

1. Dr. Jalil Shams, Deputy Minister

2. Mr. Atiqullah Atifmal, Deputy Chief of Protocol

3. Mr. Ali Jan, Department of Economic Relations

4. Mr. Samim, Department of Economic Relations

\section{others}

1. Mr. Saeed Amanullah Sadat, Governor of Kabul

2. General Ghulam Bahawoodeen, General Commander of Police for Kabul Province

3. Deputy Head of Delegate ICRC

4. Eng. Saleh, German Agro-Action

5. Director, Halo Trust

6. Mr.Claude Belleau, Deputy Res. Rep UNDP

7. Mr. Jolyon Leslie, UNCHS (Habitat)

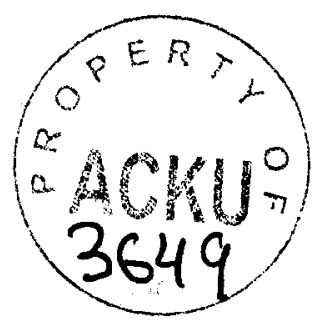

